Article - Smart Energy

\title{
Study of the Potential of Photovoltaic Microgeneration and Minigeneration from the Grid-Connected Photovoltaic Installed at UTFPR Curitiba Campus Systems
}

Camila de Oliveira Silveira $^{1^{\star}}$

https://orcid.org/0000-0002-6391-5211

Larissa Barbosa Krasnhak ${ }^{1^{*}}$

https://orcid.org/0000-0002-4896-3514

Édwin Augusto Tonolo ${ }^{*}$

https://orcid.org/0000-0002-8644-650X

Jair Urbanetz Junior ${ }^{1^{*}}$

https://orcid.org/0000-0001-9355-1730

${ }^{1}$ Universidade Tecnológica Federal do Paraná,LABENS, PPGSE, UTFPR, Curitiba,Paraná, Brasil;

Received: 2018.11.05; Accepted: 2019.07.26.

* camia.osilveira@hotmail.com; Tel.: +55-41-999726294 (C.O.S.);

larissabarbosakrasnhak@gmail.com; Tel.: +55-41-998773545 (L.B.K.); edwintonolo@gmail.com;

Tel.: +55-45-991087892 (E.A.T.); urbanetz@utfpr.edu.br; Tel.: +55-41-998335729 (J.U.J.)

HIGHLIGHTS

- South region was the second bigger in Brazil in PV power capacity in 2018.

- The city of Curitiba had 1.9 MWp installed until July 2018.

- The systems evaluated present satisfactory figures of merit values.

Abstract: Humanity is increasingly dependent on energy, which demand grows every year. Renewable energy sources are consolidated alternatives in the market, previously installed on a small scale but now thought as large plants. The correct operation, taking full advantage of the generation potential, depends on studies of the place of implantation, such as radiation levels, temperature, latitude, etc. Two photovoltaic systems installed in the city of Curitiba were studied in order to monitor their respective performances through figures of merit.

Keywords: photovoltaic system; power capacity; power generation; figures of merit.

\section{INTRODUCTION}

The concern over the preservation of the environment, the pursuit for diversification of the electric grid and the growing demand for energy have boosted the generation of 
electricity from renewable sources, such as solar power. Brazil has significant potential for electricity generation from solar energy, with solar irradiation levels higher than in countries where projects for the development of solar energy are widely recognized, such as Germany, France and Spain [1].

In order to explore the potential of solar energy, Normative Resolution 482 from 2012 created by the National Agency of Electric Energy (ANEEL) established the general conditions for the access of the distributed microgeneration and minigeneration to the electric energy distribution systems, through net metering [2]. In 2015, Normative Resolution 687 was published, updating the previous rule. It was denominated distributed microgeneration any power station with installed power of up to $75 \mathrm{kWp}$, and minigeneration those above $75 \mathrm{kWp}$ and less or equal to $5 \mathrm{MWp}$. If the generation of electricity is greater than the consumption, the consumer will have energy credits with a term of 60 months of validity. It also implemented the remote self-consumption mode, where a consumer can discount the consumption value in another own unit, provided it is served by the same distributor [3].

According to Chart 1, the southeast region stands out with the highest percentage of installed photovoltaic (PV) power, followed by the south region. Together, they account for almost $70 \%$ of installed power capacity in Brazil. Analyzing the south region, the state of Parana occupies the last position. This fact can be explained by the non-exemption of tax on transactions related to the movement of goods and services (ICMS) in Parana until 2018.

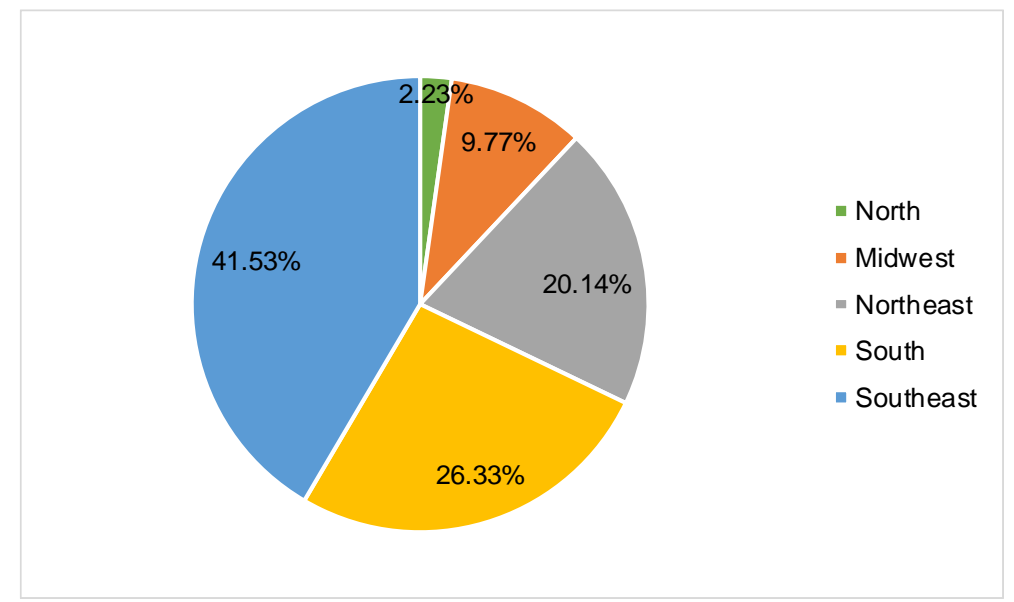

Chart 1. Installed PV power by region of Brazil.

In the analysis at the national level, the state of Minas Gerais stands out as the one with the highest in installed PV power, with approximately $75 \mathrm{MWp}$, while in the second position, Rio Grande do Sul, holds approximately 48 MWp. São Paulo, Santa Catarina, Paraná, Ceará, Rio de Janeiro, Goiás, Bahia and Pernambuco complete the list with the 10 states with the highest power installed.

By the beginning of August 2018, more than 35 thousand consumer units with distributed photovoltaic generation were registered in ANEEL, with approximately $330 \mathrm{MWp}$ of PV installed capacity [4]. In 2026, some 770,000 photovoltaic adopters are estimated under Resolution 482, totaling $3.3 \mathrm{GWp}$, sufficient to meet $0.6 \%$ of total national consumption [5].

Chart 2 presents the installed capacity of photovoltaic power generation in the city of Curitiba, almost $1.9 \mathrm{MWp}$ by July 2018. It is possible to observe the existence of a gridconnected PV system before Resolution 482 of 2012, corresponding to the Green Office (GO) at Federal University of Technology - Paraná (UTFPR), the first installed in Paraná in the concession area of Parana Company of Energy (COPEL) [6]. 


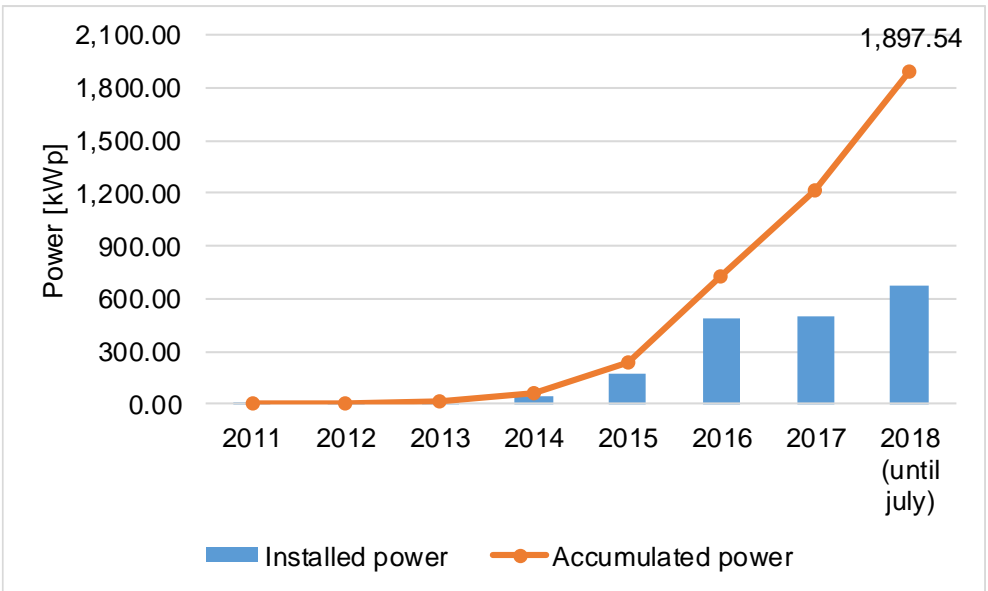

Chart 2. Installed and accumulated PV power in Curitiba.

The main goal is to monitor the installed capacity of microgeneration and photovoltaic minigeneration in Curitiba and study their contribution in the national scenario through the merit indices, irradiation indices and power generation of two grid-connected photovoltaic systems installed at UTFPR.

\section{MATERIAL AND METHODS}

\section{Description of Systems}

The UTFPR has two PV systems, both located in Curitiba Campus. One of them is installed in the roof of the GO at UTFPR's central headquarter and started its operations in December 2011, being the first PV system in Paraná. With a single-phase inverter in 220V, the nominal power reaches $2 \mathrm{~kW}$ and installed power is $2.1 \mathrm{kWp}$. It occupies an area of 15 $\mathrm{m}^{2}$, follows the roof's slope of $15^{\circ}$ and has azimuthal deviation of $22^{\circ}$ to the west from the north. The other system is operating since February 2016 and is located at Neoville's UTFPR. It has a high-efficiency three-phase inverter in $380 \mathrm{~V}$, the nominal power is $10 \mathrm{~kW}$ and installed power is $10.2 \mathrm{kWp}$. It has the inclination of $25^{\circ}$ and the orientation to the north [7].

\section{Solar Irradiation}

The annual averages of the daily total of solar irradiation are relatively high in Brazil and, despite the extensive territory with different climatic characteristics, presents a certain uniformity in the annual mean of global irradiation, as shown in Figure 1.

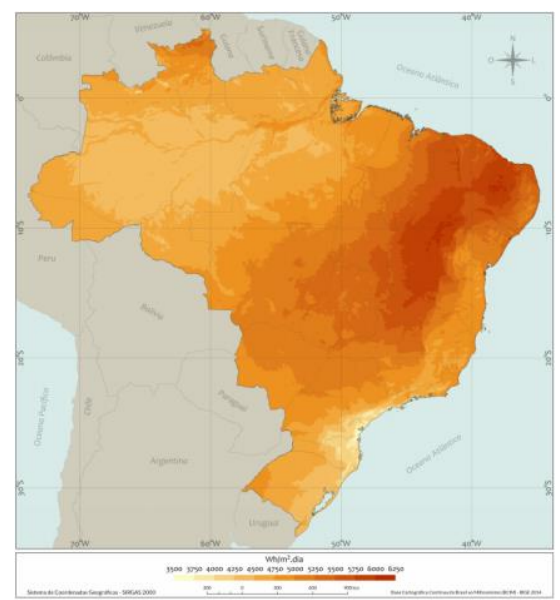

Figure 1. Daily total of annual average global irradiation.

The Northeast region has the highest annual average of daily total of horizontal global irradiation $\left(5.483 \mathrm{kWh} / \mathrm{m}^{2}\right)$, followed by the Midwest $\left(5.082 \mathrm{kWh} / \mathrm{m}^{2}\right)$ and Southeast $(4.951$ 
$\left.\mathrm{kWh} / \mathrm{m}^{2}\right)$. The North region has an index equal to $4.825 \mathrm{kWh} / \mathrm{m}^{2}$ and, finally, the South region has irradiation of $4.444 \mathrm{kWh} / \mathrm{m}^{2}$ [8].

The state of Paraná, although it belongs to the region with the lowest annual average of global irradiation, presents an annual total average of horizontal global irradiation of 1.705 $\mathrm{kWh} / \mathrm{m}^{2}$.year and the highest daily values are during the summer $\left(5.88 \mathrm{kWh} / \mathrm{m}^{2}\right.$.year) and the spring $\left(5.10 \mathrm{kWh} / \mathrm{m}^{2}\right.$.year). The lowest values are during the winter $\left(3.47 \mathrm{kWh} / \mathrm{m}^{2}\right.$.year) and the autumn (4.25 kWh/m².year). Among the mesoregions in Paraná, Curitiba is located in the denominated Metropolitan region of Curitiba, which presents the average of annual total of horizontal global irradiation of $1.492 \mathrm{kWh} / \mathrm{m}^{2}$.year, normal direct irradiation of 1.105 $\mathrm{kWh} / \mathrm{m}^{2}$.year, diffuse irradiation of $736 \mathrm{kWh} / \mathrm{m}^{2}$.year and inclined radiation at latitude equal to $1.565 \mathrm{kWh} / \mathrm{m}^{2}$.year [8].

\section{Operational Analysis}

For the operational analysis of the systems is necessary to collect the energy generation data, which are available monthly from the mass memory of their respective inverters. The data presented in Chart 3 refer to the period in which the two systems are in operation. In the annual analysis, the energy generated in Neoville is at least five times higher than from the GO.

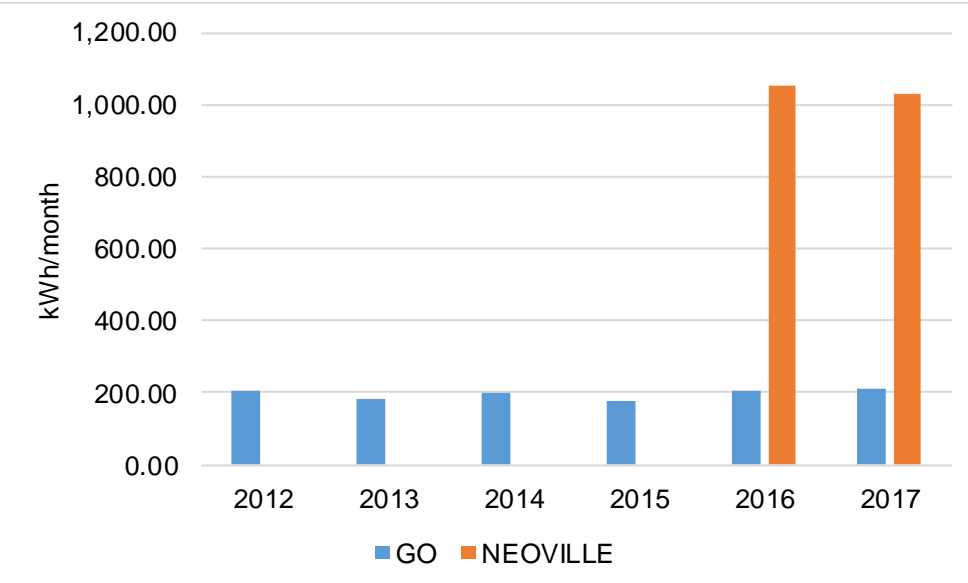

Chart 3. Monthly average power generation for each year of operation.

Considering the average electricity production of each system, the GO generated 2.364 $\mathrm{kWh} /$ year in the period from 2012 to 2017 , while Neoville produced $12.491 \mathrm{kWh} /$ year during 2016 and 2017. In a monthly analysis, the months with higher and lower energy generation are concentrated in the summer and winter seasons, respectively, a fact that is justified by the variation of the solar incidence in these times of the year, according to Table 1.

Table 1. Maximum and minimum energy generation of $G O$ and Neoville PV systems.

\begin{tabular}{|c|c|c|c|c|c|c|c|}
\hline & & 2012 & 2013 & 2014 & 2015 & 2016 & 2017 \\
\hline \multirow{3}{*}{$\begin{array}{c}\text { Minimum } \\
\text { Generation } \\
{[\mathrm{kWh}]}\end{array}$} & \multirow{2}{*}{ GO } & Jun & Jun & Jun & Jul & May & May \\
\hline & & 112 & 112 & 133 & 130 & 131 & 139 \\
\hline & Neoville & & & & & $\begin{array}{l}\text { Aug } \\
775\end{array}$ & $\begin{array}{c}\text { Jul } \\
753\end{array}$ \\
\hline \multirow{3}{*}{$\begin{array}{c}\text { Maximum } \\
\text { Generation } \\
{[\mathrm{kWh}]}\end{array}$} & \multirow{2}{*}{ GO } & Jan & Oct & Jan & Jan & Sep & Nov \\
\hline & & 273 & 258 & 304 & 249 & 258 & 258 \\
\hline & Neoville & & & & & $\begin{array}{c}\text { Apr } \\
1,329\end{array}$ & $\begin{array}{c}\text { Sep } \\
1,347\end{array}$ \\
\hline
\end{tabular}

\section{RESULTS}


In order to evaluate the performance of GO and Neoville's systems, the figures of merit were adopted to compare PV systems installed in different locations through the irradiation indexes in the PV array plane and the energy produced by the system based on installed power. This analysis presents a history of annual performance and is complementary to the studies conducted by [9], in addition to confronting them with others systems in operation in the country.

\section{Capacity Factor}

The Capacity Factor (CF) of PV systems is expressed in Equation 1 and represents the ratio between the actual energy generated by the system and the energy that could be generated if the system operated $100 \%$ of the time at its nominal power in a given period, usually one year, that is, 8,760 hours [10].

$$
C F=\frac{\text { generated energy }}{\text { nominal power }{ }^{*} \text { time }}
$$

The capacity factors of the systems are calculated monthly and Chart 4 presents the annual averages of this index for the GO and Neoville, referring to the years in which both are in operation.

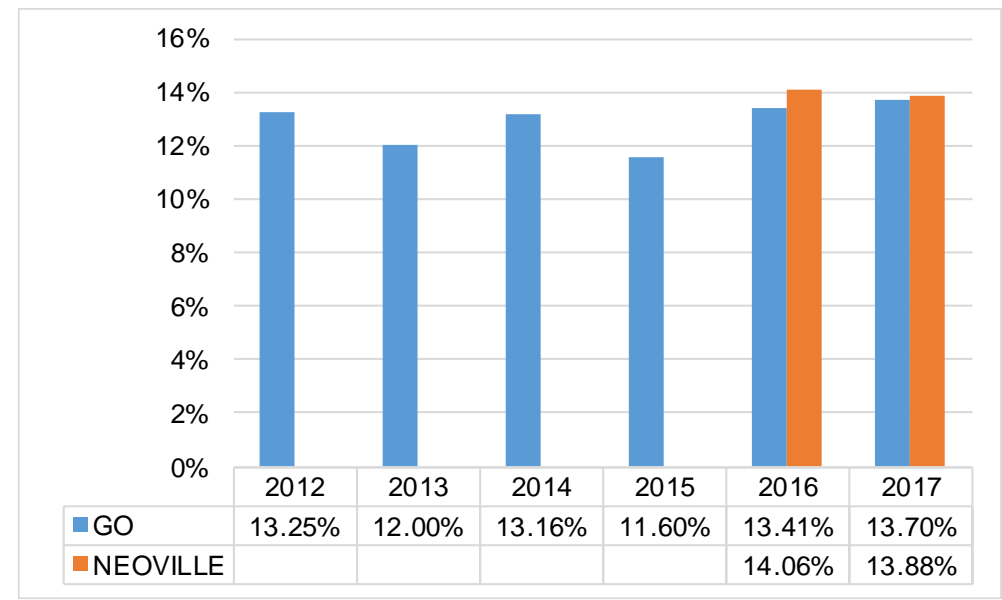

Chart 4. Annual averages of CF for GO and Neoville.

In six years of operation, the GO presented an average CF of $12.85 \%$. For Neoville, the average was 13.97\%, considering the years 2016 and 2017.

\section{Final Yield}

The Final Yield (YF) of PV systems can be calculated according to Equation 2 and establishes the relation between the generated energy, in $\mathrm{kWh}$, per $\mathrm{kWp}$ of the system installed power [10].

$$
\mathrm{YF}=\frac{\text { generated energy }}{\text { installed power }}
$$

The final yields of the related systems are calculated monthly and Chart 5 shows the annual results of this index for the GO and Neoville for the years in which both are in operation. 


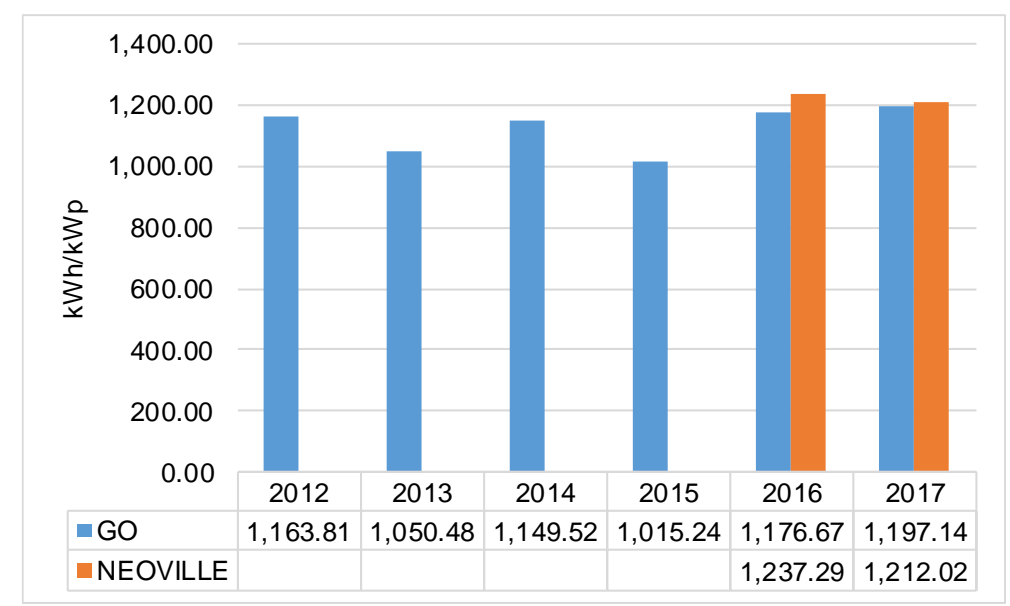

Chart 5. Annual results of YF for GO and Neoville.

In six years of operation, the GO showed an average YF of $1,125.48 \mathrm{kWh} / \mathrm{kWh}$. For Neoville, the average was 1,224.66 kWh/kWh, considering the years 2016 and 2017.

\section{Performance Ratio}

The performance ratio (PR) of PV systems corresponds to the capacity of the system to convert the available solar energy on the plane of the photovoltaic panels into electrical energy, considering the losses that occurred in this energy conversion process [10]. This index is expressed as a percentage, according to Equation 3.

$$
\mathrm{PR}=\frac{\mathrm{YF}}{\text { irradiation } / 1000}
$$

The performance ratios are calculated monthly and Chart 6, and shows the annual averages of this index for GO and Neoville for the years in which both are in operation.

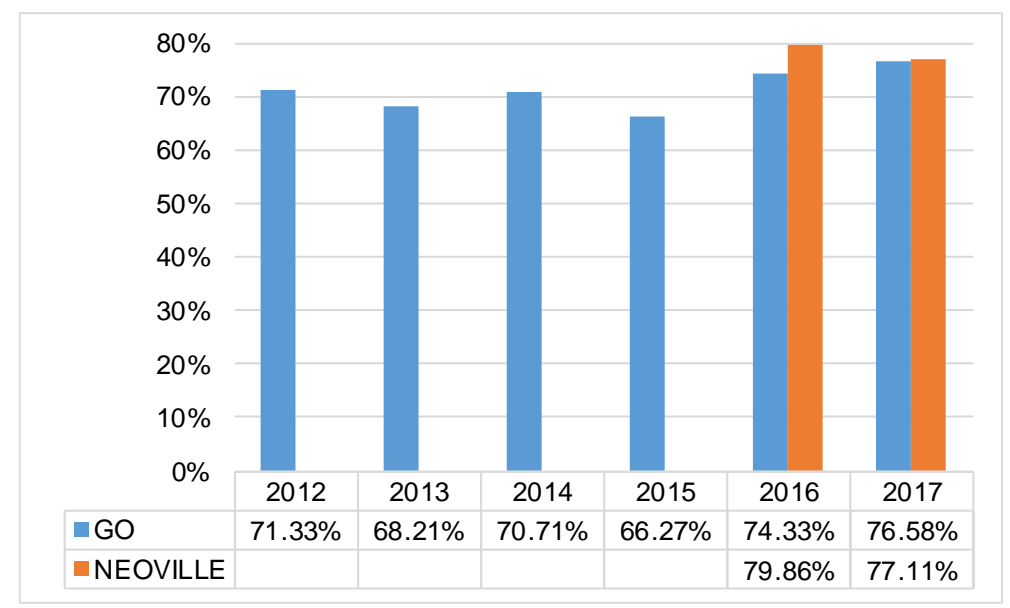

Chart 6. Annual averages of PR for GO and Neoville.

In six years of operation, the GO had an average PR of $71.24 \%$. For Neoville, the average is $78.48 \%$, considering the years 2016 and 2017 .

\section{DISCUSSION}

The expected capacity factor in Brazil comprises the percentages between $13 \%$ and $18 \%$, varying according to the availability of the solar resource, the technology used in the photovoltaic system and the adopted design [10]. There is a significant difference in the values that evaluate the performance of a PV system depending on the region of Brazil. 
Estimates of capacity factors and final yields for each region of the country are presented in Table 2.

Table 2. Expected CF and YF for each country's region.

\begin{tabular}{ccc}
\hline Region & CF [\%] & YF [kWh/kWp] \\
\hline North & 17.10 & 1,500 \\
Northeast & 18.10 & 1,580 \\
Midwest & 16.60 & 1,460 \\
Southeast & 14.80 & 1,300 \\
South & 14.20 & 1,250 \\
\hline
\end{tabular}

The difference in estimates is explained by the variation in solar incidence in the Brazilian territory, where the northeast region has the highest solar potential, enabling the generation of energy by photovoltaic technology [8]. Some case studies were considered, one in each region of the country, in order to verify if the figures of merit of PV system are expected according to their installation locations. The Table 3 presents the main performance evaluation parameters of such systems, all installed with polycrystalline modules, in order to compare them with the results obtained from the PV systems installed at UTFPR Curitiba Campus.

Table 3. Evaluation parameters of PV systems installed in different locations.

\begin{tabular}{ccccccc}
\hline Region & State & System & $\begin{array}{c}\text { Installed } \\
\text { power }\end{array}$ & CF [\%] & $\begin{array}{c}\text { YF } \\
\text { [kWh/kWp] }\end{array}$ & PR [\%] \\
\hline North & PA & Belem & 2.4 & 20.98 & 1,838 & 74.3 \\
Northeast & PI & Floriano & 171.6 & 17.13 & 1,493 & 74.0 \\
Midwest & MT & Itiquira & 9.0 & 17.20 & 1,514 & 74.9 \\
Southeast & SP & Sao Paulo & 70.0 & 13.90 & 1,115 & 65.8 \\
South & RS & Aratiba & 9.0 & 13.80 & 1,214 & 78.7 \\
\hline
\end{tabular}

Analyzing Table 3, the results regarding the capacity factor and final yield are adequate when compared to the expected indexes for each region of the country. The differences that occur can be justified by the installation conditions, inverter efficiency and the variations of solar resource, which suffers significant weather variations throughout the day, such as the presence of cloudiness, making PV systems able to operate in nominal power for a few hours [16]. The results of the systems installed at UTFPR Curitiba Campus also contribute to the affirmation of this discussion, as they indicate capacity factors ranging from $11.60 \%$ to $14.06 \%$, and final yields between $1,015.24 \mathrm{kWh} / \mathrm{kWp}$ and $1,237.29 \mathrm{kWh} / \mathrm{kWp}$. Both parameters of these two PV systems indicate their operations occur as expected, since the expected capacity factor in Curitiba is $12.1 \%$ [17] and the annual final yield on the inclined latitude plane comprises the range of $1,125 \mathrm{kWh} / \mathrm{kWp}$ to $1,200 \mathrm{kWh} / \mathrm{kWp}$ [18]. Regarding the performance ratio, the value of $75 \%$ is the most adopted for design purposes, being used internationally in the elaboration of photovoltaic maps [18]. The PV systems at UTFPR, as well as those found in Table 3, can be considered adequate, since they comprise values between $70 \%$ and $80 \%$, except for the system located in Sao Paulo, which presented a value below the standard average.

\section{CONCLUSION}

The increasing evolution of installed capacity per photovoltaic power plant in Brazil indicates that PV systems can be widely installed in buildings as an option to produce electricity. In the microgeneration and minigeneration scenario, net metering provided advantages to the owner of the system since Normative Resolution 482 took effect. 
Although the largest solar potential for photovoltaic power generation is concentrated in regions where irradiation rates are high, the solar distributed generation market has a larger representation in regions with greater economic development, such as south and southeast. Given the growth of photovoltaic energy generated from PV systems in Curitiba, the monitoring of the systems deployed at UTFPR becomes relevant as the collected data are updated in order to increase the reliability of the study and maintain a history since the beginning its operation.

In the analysis of the figures of merit, the irradiation index at the installation site, the module inclinations and azimuthal orientations have interference in the solar resource available for the systems: the panel plane and the geographical orientation where the systems are located reflect on its final productivity. Besides these justifications, the inverter technology, the shading and the cleaning of panels are fundamental in the performance comparison between the systems, where Neoville presents optimum installation conditions, such as better orientation to the geographic north and photovoltaic panels inclination equivalent to the local latitude.

Acknowledgments: The authors would like to thank UTFPR for the support and infrastructure available for the development of this research and COPEL - Distribution for the support and funding of the resources for the realization of this R\&D project "RD 2866-0464 / 2017 - METHODOLOGY FOR ANALYSIS, MONITORING AND MANAGEMENT BY ENCOURAGED SOURCES".

\section{REFERENCES}

1. Nascimento, R.L. Technical study: Solar Energy in Brazil: Situation and Prospects, 2017.

2. National Electrical Energy Agency: Normative Resolution No. 482. Available online: http://www2.aneel.gov.br/cedoc/ren2012482.pdf (accessed 9 August 2018).

3. National Electrical Energy Agency: Normative Resolution No. 687. Available online: http://www2.aneel.gov.br/cedoc/ren2015687.pdf (accessed 9 August 2018).

4. National Electrical Energy Agency: Consumer Units with Distributed Generation. Available online: http://www.aneel.gov.br/outorgas/geracao/-/asset_publisher/mJhnKli7qcJG/content/ registro-de-central-geradora-de-capacidade-reduzida/655808 (accessed 09 August 2018).

5. Ministry of Mines and Energy. Energy research company. Decennial Energy Expansion Plan 2026, Brasilia, 2017.

6. Urbanetz Junior, J.; Chinvelski, T.; Simão, C. A. F.; Makishi, L. M. M. First grid-connected photovoltaic system approved by Copel. V CBENS 2014, 01-08.

7. Urbanetz Junior, J.; Tiepolo G. M.; Casagrande Junior, E. F.; Tonin F. S.; Mariano, J. D. Photovoltaic Distributed Generation: The Case of UTFPR Photovoltaic Systems in Curitiba. $X$ CBPE 2016, 01-13.

8. Pereira, E., Martins, F., Gonçalves, A., Costa, R., Lima, F., Rüther, R., Abreu, S., Tiepolo, G., Pereira, S. e Souza, J. Brazilian Atlas of Solar Energy, 2nd ed.; National Space Research Institute: São José dos Campos, Brazil, 2017; pp. 09-68.

9. Silveira, C. O; Moreira, A. R.; Moreira, B. L. P; Urbanetz Junior, J. Feasibility study of distributed generation by grid-connected photovoltaic systems in Curitiba. IV Smart Energy 2017, 01-06.

10. Benedito, R. S. Characterization of distributed electricity generation through grid-connected photovoltaic systems in Brazil, from the technical, economic and regulatory aspects. Master Degree, University of São Paulo, São Paulo, 2009.

11. Quaglia, R. B. Incentive for distributed generation with photovoltaic systems: scenarios for the Brazilian electric sector: scenarios for the brazilian electric sector. Master Degree, Federal University of the ABC, Santo André, 2010.

12. Raimo, P. A.; Sobreira, R. L.; Bueno, E. A. Performance Analysis of the 70 Kwp Photovoltaic Plant: Case Study at São Paulo Federal Institute. VII CBENS 2018, 01-08.

13. Teles, M. B.; Rodrigues, M. J. S.; Cavalcante, R. L.; Pinho, J. T.; Macêdo, N.; Oliveira, L. G. M. Performance analysis of two grid-connected photovoltaic systems installed in northern Brazil. $\mathrm{VI}$ CBENS 2016, 01-08. 
14. Lima, J. B.; Gonçalves, J. A. Comparative performance analysis between grid-connected photovoltaic systems installed in Piauí and Europe using merit figures. VII CBENS 2018, 01-08.

15. Dolla, R. Performance comparison of a photovoltaic system composed of six technologies in tropical and subtropical climate. Undergraduate thesis, Federal University of Santa Catarina, Florianópolis, 2017

16. Almeida, M. P. Qualification of grid-connected photovoltaic systems. Master Degree, University of São Paulo, São Paulo, 2012.

17. Nakabayashi, R. K. Photovoltaic microgeneration in Brazil: current conditions and future prospects. Master Degree, University of São Paulo, São Paulo, 2014.

18. Tiepolo, G; Pereira, E.; Urbanetz Junior, J.; Pereira, S.; Gonçalves, A.; Lima, F.; Costa, R.; Alves, A. Solar Energy Atlas - Paraná, 1st ed.; National Space Research Institute: São José dos Campos, Brazil, 2017; pp. 10-84.

(C) 2018 by the authors. Submitted for possible open access publication under the terms and conditions of the Creative Commons Attribution (CC BY NC) license (http://creativecommons.org/licenses/by/4.0/). 